\title{
PEMBINAAN DAN PELATIHAN MODEL PENCATATAN, PELAPORAN, PENGAUDITAN, DAN PERENCANAAN KEUANGAN ORGANISASI KEAGAMAAN DI GMAHK KECAMATAN TONDANO BARAT DAN KECAMATAN TONDANO SELATAN
}

\author{
Joseph P. Kambey \\ Fakultas Ekonomi, UNIMA
}

\begin{abstract}
Kegiatan ini bertujuan untuk memberikan pelatihan kepada anggota gereja, khususnya para pimpinan gereja tentang model pencatatan, pelaporan, pengauditan,dan perencanaan keuangan gereja (organisai nir laba), sehingga para pimpinan gereja dapat memiliki pemahaman yang baik dan dapat menerapkannya dalam setiap program dan kegiatan gereja. Adapun sasaran dari kegiatan ini adalah pembinaan dan pelatihan kepada para pimpinan gereja-gereja (GMAHK) diwilayah Kecamatan Tondano Barat dan Tondano Selatan.

Pembinaan dan pelatihan ini bermanfaat bagi para pimpinan gereja, untuk memahami tentang model pencatatan dan pelaporan keuangan serta dapat melakukan pengauditan serta perencanaan keuangan yang realistis, hal ini dilakukan dalam rangka meningkatkan transparansi serta menjaga relevansi dan reliabilitas atas laporan pertanggung jawaban dalam bentuk laporan keuangan yang dibuat.

Rencana materi yang akan diberikan mencakup: a)Konsep Dasar Pencatatan Aktivitas Keuangan; b) Konsep Dasar Pelaporan Keuangan; c) Konsep Dasar Perencanaan Keuangan. Metode yang diguanakan dalam kegiatan pengabdian ini adalah metode ceramah, Tanya jawab, studi kasus, dan praktek lapangan. Teknik yang digunakan dalam kegiatan ini adalah secara individual dan kelompok. Evaluasi akan dilakukan baik pada setiap kegiatan pembinaan dan pelatihan maupun pada saat kegiatan berakhir.

Berdasarkan hasil dan pembahasan kegiatan pengabdian kepada masyarakat yang telah diuraikan sebelumnya, dapat ditarik kesimpulan sebagai berikut: 1) Pemahaman peserta tentang pencatatan, pelaporan, pengauditan, laporan keuangan organisasi gereja semakin baik setelah mengikuti pelatihan penyusunan laporan keuangan, terutama bagi anggota yang terlibat langsung dalam proses penyusunan laporan keuangan; dan 2) Kemampuan peserta pelatihan melakukan perencanaan keuangan pada simulasi dengan bahan yang disiapkan telah cukup baik.

Keywords: organisasi keagamaan, model pencatatan, pelaporan, pengauditan, dan perencanaan keuangan.
\end{abstract}

\section{PENDAHULUAN}

\section{Analisis Situasi}

Pembangunan masyarakat merupakan hal yang sangat mendesak untuk diperhatikan, baik oleh Pemerintah maupun organisasi-organisasi yang bergerak dibidang pembangunan masyarakat. Salah satu organisasi yang berperan sangat besar dalam membangun masyarakat yang seutuhnya adalah organisasi keagamaan. Perguruan tinggi yang memiliki sumber- sumber daya yang dapat diandalkan dalam berpikir strategis untuk membangun suatu komunitas masyarakat terntentu memang sangat dibutuhkan oleh masyarakat, khususnya organisasi keagamaan. Hal ini sangat sesuai dengan tridharma perguruan tinggi atau 3 fungsi pokok yaitu Pendidikan, dan Pengajaran, Penelitian, dan Pengabdian kepada Masyarakat.

Kecamatan Tondano Barat dan Tondano Selatan terletak di daerah yang 
sangat strategis yaitu penghubungan antara Kota Tomohon dan Tondano. Selain itu, Kecamatan Tondano Selatan menjadi pusat aktivitas mahasiswa yang menempuh pendidikan di Universitas Negeri Manado. Penduduk kedua Kecamatan ini berjumlah \pm 20.000 jiwa yang sebagian besar diantaranya adalah mahasiswa pendatang. Mayoritas penduduk di kedua Kecamatan ini menjalankan aktivitas keagamaannya di bawah naungan organisasi keagamaan resmi yang ada di Kecamatan tersebut. Salah satu organisasi keagamaan yang ada di kecamatan tersebut adalah Gereja Masehi Advent Hari Ketujuh. Ada 6 Gereja GMAHK yang resmi berdiri di Kecamatan Tondano Barat dan Tondano Selatan, dan \pm 1000 jiwa yang terdaftar dsebagai anggota GMAHK di wilayah tersebut. Masing-masing gereja tersebut memiliki program-program atau kegiatan kerohanian yang sudah maupun yang akan dilaksanakan. Setiap program yang dilaksanakan tidak akan terlepas dari perencanaan dana dan pelaporan aliran dana kegiatan. Untuk itu diperlukan pembinaan dan pelatihan dibidang keuangan yang relevan dengan tipe organisainya yaitu organisai nir laba.

Berdasarkan survey awal dari penulis, tergambar bahwa praktek keuangan yang diimplementasikan belum bias dianggap wajar oleh karena masih terdapat kekeliruan dalam pelaporan serta tidak ada prosedur atau ketentuan untuk dilakukannya pengauditan terhadap laporan keuangan yang dibuat. Hal ini akan 58 menimbulkan keresahan bagi anggota organisai tersebut jika terjadi beda pendapat atas laporan keuangan yang dibuat. Kemudian, anggota organisasi tidak memiliki pemahaman mengenai perencanaan keuangan sehingga mengalami kendala dalam menentukan perencanaan keuanagn untuk program kerja periode yang akan datang. Hal inilah yang perlu dilakukan pembinaan dan pelatihan yang tepat sasaran dengan harapan pembinaan dan pengetahuan terhadap bidang keuangan khususnya pada sector organisasi nir laba (gereja) dapat sesuai dengan harapan.

Oleh sebab itu, sebagai perguruan tinggi dalam hal ini UNIMA ( Universitas Negeri Manado) merasa terpanggil untuk melakukan kegiatan pengabdian pada gereja-gereja (GMAHK) di Kecamatan Tondano Barat dan Selatan, dengan focus pembinaan:

a. Aplikasi pencatatan dan pelaporan keuangan organisasi gereja.

b. Teknik pengauditan laporan keuangn organisai gereja.

c. Teknik perencanaan keuangan organisasi gereja.

Masalah yang dihadapi oleh anggota dan pimpinan gereja sebagai berikut:

1) Anggota gereja, sebagian besar belum memahami model pencatatan dan pelaporan keuangan gereja sehingga masih sering terjadi perbedaan pendapat atas laporan keuangan yang dibuat. 
2) Pimpinan gereja, belum memahami teknik pengauditan laporan keuangan gereja, sehingga laporan keuangan yang dibuat sering dianggap tidak wajar.

3) Anggota gereja, sebagian besar belum memahami model perencanaan keuangan yang benar sehingga perencanaan keuangan yang dinuat selalu tidak tepat sasaran.

4) Belum adanya pembinaan dan pelatihan yang dilakukan oleh pihak gereja belum memiliki model yang tepat untuk dipraktekkan.

\section{Tujuan dan Manfaat}

Kegiatan ini bertujuan untuk memberikan pelatihan kepada anggota gereja, khususnya para pimpinan gereja tentang model pencatatan, pelaporan, pengauditan,dan perencanaan keuangan gereja (organisai nir laba), sehingga para pimpinan gereja dapat memiliki pemahaman yang baik dan dapat menerapkannya dalam setiap program dan kegiatan gereja.

Adapun sasaran dari kegiatan ini adalah pembinaan dan pelatihan kepada para pimpinan gereja-gereja (GMAHK) diwilayah Kecamatan Tondano Barat dan Tondano Selatan.

Pembinaan dan pelatihan ini bermanfaat bagi para pimpinan gereja, untuk memahami tentang model pencatatan dan pelaporan keuangan serta dapat melakukan pengauditan serta perencanaan keuangan yang realistis, hal ini dilakukan dalam rangka meningkatkan transparansi serta menjaga relevansi dan reliabilitas atas laporan pertanggung jawaban dalam bentuk laporan keuangan yang dibuat.

\section{Kerangka Pemecahan Masalah}

Rencana materi yang akan diberikan mencakup konsep dasar pencatatan aktivitas keuangan, konsep dasar pelaporan keuangan, konsep dasar perencanaan keuangan. Metode yang diguanakan dalam kegiatan pengabdian ini adalah metode ceramah, Tanya jawab, studi kasus, dan praktek lapangan. Teknik yang digunakan dalam kegiatan ini adalah secara individual dan kelompok. Evaluasi akan dilakukan baik pada setiap kegiatan pembinaan dan pelatihan maupun pada saat kegiatan berakhir. Pelaksanaan akan diawali dengan pendaftaran peserta, persiapan kegiatan di Aula Gereja Masehi Advent Hari Ketujuh Perum Unima, dan pelaksanaan penyuluhan dan pelatihan selama 3 hari.

\section{KAJIAN TEORI}

\section{Konsep Dasar Akuntansi}

Jusup (2005) menyatakan bahwa definisi akuntansi dapat dirumuskan dari dua sudut pandang, yaitu definisi dari sudut pemakai jasa akuntansi, dan dari sudut proses kegiatannya. Ditinjau dari sudut pemakainya, akuntansi dapat didefinisikan sebagai "suatu disiplin yang menyediakan informasi yang diperlukan untuk melaksanakan kegiatan secara efisien dan mengevaluasi kegiatan-kegiatan suatu 
organisasi". Informasi yang dihasilkan akuntansi diperlukan untuk:

1. Membuat perencanaan efektif, pengawasan dan pengambilan keputusan oleh manajemen.

2. Pertanggungjawaban organisasi kepada para investor, kreditur, donatur, Pemerintah dan sebagainya.

Dari defenisi tersebut di atas, dapat disimpulkan bahwa akuntansi diselenggarakan dalam suatu organisasi, dimana informasi akuntansi yang dihasilkan adalah informasi tentang organisasi tersebut. Informasi akuntansi sangat penting dalam menyelenggarakan kegiatan organisasi, khususnya digunakan dalam pengambilan keputusan internal organisasi.

Ditinjau dari sudut proses kegiatan,akuntansi dapat didefinisikan sebagai "seni pencatatan, penggolongan, peringkasan, pelaporan, dan penganalisisan data keuangan suatu organisasi". Definisi ini menunjukkan bahwa kegiatan akuntansi merupakan tugas yang kompleks dan menyangkut bermacam-macam kegiatan. Pada dasarnya akuntansi harus bias mengidentifikasikan data mana yang berkaitan atau relevan dengan keputusan yang akan diambil, memproses atau menganalisa data yang relevan dan mengubah data menjadi informasi yang dapat digunakan untuk pengambilan keputusan.

Bastian (2007) mendefinisikan akuntansi sebagai suatu proses pencatatan, pengklasifikasian, pengikhtisaran, dan 60 pelaporan transaksi-transaksi keuangan entitas sebagai suatu kesatuan dari unitunitnya serta penafsiran atas hasil-hasil dari aktivitas yang dilakukan. Dengan demikian dapat disimpulkan bahwa akuntansi merupakan suatu kegiatan yang dilakukan untuk menghasilkan suatu sistem informasi berupa laporan keuangan yang dibutuhkan oleh berbagai pihak baik pihak internal maupun pihak eksternal organisasi.

\section{Sistem Pengelolaan Keuangan Gereja}

Dengan Akuntansi Akuntansi pada dasarnya adalah merupakan kegiatan yang mengolah transaksi-transaksi keuangan menjadi informasi keuangan yang siap pakai. Kegiatan yang dilakukan dalam proses akuntansi meliputi: 1) pencatatan, 2) penggolongan, 3) peringkasan, 4) pelaporan dan 5) penganalisisan data keuangan dari suatu organisasi. Proses akuntansi tersebut akan menghasilkan informasi keuangan yang berguna baik bagi pihak internal organisasi dalam pengambilan keputusan yang berkaitan dengan keuangan maupun eksternal organisasi dalam menilai, mengevaluasi, menganalisis dan memonitoring.

Siklus akuntansi merupakan proses akuntansi mulai dari pencatatan transaksi keuangan sampai dengan penyusunan laporan keuangan pada akhir periode. Pada dasarnya siklus akuntansi dapat dibagi sebagai berikut:

1. Membuat atau menerima bukti pencatatan di mana biasanya sebuah 
entitas mempunyai form voucher (bukti pencatatan) sendiri, atau bukti lain yang bisa berupa kwitansi atau lainnya.

2. Mencatat dalam buku jurnal.

3. Memindahkan data jurnal ke buku besar.

4. Menyusun laporan keuangan.

Siklus akuntansi dalam organisasi gereja dapat dikelompokkan dalam empat tahap, yaitu (Bastian, 2005):

- Tahap pencatatan dan Penggolongan:

$\checkmark$ Kegiatan pengidentifikasian dan pengukuran bukti transaksi serta bukti pencatatan.

$\checkmark$ Kegiatan pencatatan bukti transaksi ke dalam buku harian atau jurnal.

$\checkmark$ Memindahbukukan (posting) dari jurnal berdasarkan kelompok atau sejenisnya ke dalam akun buku besar

- Tahap peringkasan:

$\checkmark$ Penyusunan neraca saldo (trial balance) berdasarkan akun-akun buku besar.

$\checkmark$ Pembuatan ayat jurnal penyesuaian

$\checkmark$ Penyusunan kertas kerja (work sheet).

$\checkmark$ Pembuatan ayat jurnal penutup (closing entries).

$\checkmark$ Pembuatan neraca saldo setelah penutupan.

$\checkmark$ Pembuatan ayat jurnal pembalik.

- Tahap pelaporan:

$\checkmark$ Laporan Aktivitas (Surplus/defisit)

$\checkmark$ Laporan arus kas

$\checkmark$ Neraca
- Tahap analisis:

$\checkmark$ Analisis laporan keuangan dengan menggunakan analisis rasio.

\section{Sistem Informasi Akuntansi Organisasi}

Beberapa hasil penelitian (Pinasti, Hariyanto, Idrus, Marbun) dalam Pinasti (2007) menunjukkan bahwa kelemahan organisasi sosial di Indonesia adalah pada umumnya organisasi sosial tidak menguasai dan tidak menerapkan sistem keuangan yang memadai. Organisasi sosial tidak atau belum memiliki dan menerapkan catatan akuntansi dengan ketat dan disiplin dengan pembukuan yang sistematis dan teratur. Organisasi sosial secara umum menganggap bahwa informasi akuntansi tersebut tidak penting, selain sulit diterapkan juga membuang waktu dan biaya. Hal terpenting bagi organisasi sosial adalah bagaimana menyusun laporan keuangan yang banyak tanpa repot menerapkan akuntansi. Kenyataan ini juga didukung oleh hasil penelitian Musmini (2008) menunjukkan bahwa kebanyakan organisasi sosial tidak menyelenggarakan catatan akuntansi, beberapa yang mempunyai catatan keuangan modelnya sangat sederhana dan tidak sistematis.

Pembukuan untuk organisasi sosial terdiri dari dua proses yaitu merancang pembukuan dan implementasi pembukuan (Golrida, 2008). Pada proses merancang pembukuan terdiri dari beberapa tahap yaitu:

1. melakukan pertimbangan dasar 
2. mengembangkan kerangka pembukuan

3. menetapkan bukti-bukti transaksi

4. menetapkan siklus akuntansi

5. merancang format buku besar

Proses implementasi merupakan hasil akhir dari pembukuan yang dilakukan, dalam hal ini berupa laporan keuangan. Pada organisasi sosial sangat memerlukan informasi kinerja tentang laba/rugi usaha serta informasi posisi keuangan yaitu harta, kewajiban dan modal usaha. Laporan harus disajikan secara kontinyu (berkelanjutan) dengan prinsip konsistensi sehingga laporan mempunyai daya banding (komparabilitas), sehingga memudahkan perusahaan menilai perkembangan usahanya dari waktu ke waktu atau posisi perusahaan dibanding perusahaan lain. Prinsip daya banding dan prinsip konsistensi merupakan persyaratan dalam penyajian laporan keuangan organisasi sosial agar laporan keuangan bermanfaat dalam mendukung perkembangan perusahaan.

\section{Gambaran Penyusunan Laporan Keuangan}

Informasi keuangan dalam suatu sistem, yang digunakan untuk mengatur proses awal pengumpulan data hingga sampai pada proses pengelolaan data menjadi suatu informasi yang siap digunakan baik oleh pihak intern maupun ekstern. Karena informasi yang dibutuhkan adalah informasi keuangan maka digunakan sistem akuntansi. Sistem akuntansi telah banyak didefinisikan oleh para ahli dalam 62 bidang akuntansi. Mereka memberikan pendapat yang berbeda-beda tetapi mempunyai arti yang hampir sama.

Mulyadi (2001: 3) mengatakan bahwa sistem akuntansi adalah" organisasi formulir, catatan, dan laporan yang di koordinasikan sedemikian rupa untuk menyediakan informasi keuangan yang dibutuhkan oleh manajemen guna memudahkan pengelolaan perusahaan". Sedangkan Samsiyah Siti (1981: 4) mengatakan bahwa sistem akuntansi adalah "suatu komponen organisasi yang mengumpulkan, menggolongkan, menganalisa, dan mengkomunisasikan informasi keuangan yang relevan untuk mengambil keputusan kepada pihak-pihak ekstern maupun pihak-pihak intern". Jadi dapat disimpulkan bahwa sistem akuntansi adalah suatu sistem untuk mengolah data keuangan dalam perusahaan atau organisasi baik organisasi sosial atau profit dengan tujuan menghasilkan informasi keuangan yang diperlukan oleh perusahaan, organisasi serta pihak- pihak yang berkepentingan lainnya.

Ada beberapa faktor- faktor yang di pertimbangkan dalam penyusunan sistem akuntansi yaitu:

1. Sistem akuntansi harus memenuhi unsur cepat yaitu suatu sistem akuntansi harus mampu menyediakan informasi yang di perlukan pada waktunya, dapat memenuhi kebutuhan dan kualitas yang sesuai. 
2. Sistem akuntansi yang disusun harus memenuhi prinsip aman yaitu bahwa sistem akuntansi harus dapat membantu serta menjaga keamanan harta milik perusahaan.

3. sistem akuntansi yang disusun harus memenuhi prinsip murah yaitu bahwa biaya untuk penyelenggaraan sistem akuntansi dapat ditekan sehingga relatif tidak mahal.

Mulyadi (2001: 3) mengatakan bahwa sistem adalah "suatu jaringan prosedur yang dibuat menurut pola yang terpadu untuk melaksanakan kegiatan pokok perusahaan”. sedangkan W. Gerald Cole dalam Zaki Baridwan (1998: 3) mengatakan sistem adalah " kerangka kerja dari prosedur-prosedur yang saling berhubungan disusun dengan skema yang menyeluruh untuk melaksaksanakan suatu kegiatan perusahaan". Dari kedua pendapat diatas dapat di simpulkan bahwa sistem terdiri dari jaringan prosedur yang saling berkaitan untuk mencapai tujuan tertentu.

$$
\text { Menurut Mulyadi (2001: 3) }
$$

menyebutkan elemen- elemen pembentuk sistem yaitu:

1. Formulir, merupakan dokumen yang digunakan untuk merekam terjadinya transaksi. Formulir sering disebut dengan istilah dokuman, karena dengan formulir ini peristiwa yang terjadi dalam organisasi direkam (didokumentasikan) diatas secarik kertas. Formulir sering juga disebut dengan istilah media, karena formulir merupakan media untuk mencatat peristiwa yang terjadi dalam organisasi kedalam catatan. Dengan formulir ini, data yang bersangkutan dengan transaksi direkam pertama kalinya sebagai dasar pencatatan dalam catatan. Contoh formulir adalah : faktur penjualan, bukti kas keluar, dan cek. Dengan faktur penjualan misalnya, direkam data mengenai nama pembeli, alamat pembeli, jenis dan kuantitas barang yang dijual, harga barang, tanda tangan otorisasi, dan sebagainya. Dengan demikian faktur penjualan digunakan untuk mendokumentasikan transaksi penjualan. Informasi yang tercamtum dalam faktur penjualan tersebut kemudian dicatat dalam jurnal penjualan dan buku pembantu piutang. Dengan demikian faktur penjualan tersebut merupakan media pencatatan kedalam jurnal dan media posting kedalam buku pembantu piutang. Dalam sistem akuntansi secara manual, media yang digunakan merekam prtama kali data transaksi keuangan adalah formulir yang dibuat dari kertas (paper form). Dalam sistem akuntansi dengan komputer (computerized system) digunakan berbagai macam media untuk mamasukkan data kedalam sistem pengolahan data seperti : papan ketik (keyboard), optical and magnetic character and code, mice, voice, touch sensors, and cats. 
2. Jurnal, merupakan catatan akuntansi pertama yang digunakan untuk mencatat, mengklasifikasikan, dan meringkas data keuangan dan data lainnya. Seperti telah disebutkan diatas, sumber informasi pencatatan dalam jurnal ini adalah formulir. Dalam jurnal ini data keuangan untuk pertama kalinya diklasifikasikan menurut penggolongan yang sesuai dengan informasi yang akan disajikan dalam laporan keuangan. Dalam jurnal ini pula terdapat kegiatan peringkasan data, yang hasil peringkasannya (berupa jumlah rupiah transaksi tertentu) kemudian di-posting ke rekening yang bersangkutan dalam buku besar. Contoh jurnal adalah jurnal penerimaan kas, jurnal pembelian, jurnal penjualan, dan jurnal umum.

3. Buku Besar (general ledger), terdiri dari rekening- rekening yang digunakan untuk meringkas data keuangan yang telah dicatat sebelumnya dalam jurnal. Rekening- rekening dalam buku besar ini disediakan sesuai dengan unsurunsur informasi yang akan disajikan dalam laporan keuangan. Rekening buku besar ini disatu pihak dapat dipandang sebagai wadah untuk menggolongkan data keuangan, di pihak lain dapat dipandang pula sebagai sumber informasi keuangan untuk penyajian laporan keuangan.

4. Buku Pembantu, jika data keuangan yang digolongkan dalam buku besar diperlukan rinciannya lebih lanjut, dapat dibentuk buku besar (subsidiary ledger). Buku pembantu ini terdiri dari rekening- rekening pembantu yang merinci data keuangan yang tercantum dalam rekening tertentu dalam buku besar. Sebagai contoh, jika rekening piutang dagang yamg tercantum dalam neraca perlu dirinci lebih lanjut menurut nama debitur yang jumlahnya 60 orang, dapat dibentuk buku pembantu piutang yang berisi rekeningrekening pembantu piutang kepada tiap- tiap debitur tersebut. Buku besar dan buku pembantu merupakan catatan akuntansi akhir (book of final entry), yang berarti tidak ada catatan akuntansi lain lagi sesudah data akuntansi diringkas dan digolongkan dalam rekening buku besar dan buku pembantu. Buku besar dan buku pembantu disebut sebagai catatan akuntansi akhir juga karena setelah data akuntansi keuangan dicatat dalam bukubuku tersebut, proses akuntansi selanjutnya adalah penyajian laporan keuangan, bukan pencatatan lagi kedalam catatan akuntansi.

5. Laporan, hasil akhir proses akuntansi adalah laporan keuangan yang dapat berupa neraca, laporan rugi laba, laporan perubahan laba yang di tahan, laporan harga pokok produksi, laporan biaya pemasaran, laporan harga pokok penjualan, daftar umur piutang, daftar utang yang akan dibayar, daftar saldo 
persediaan yang lambat penjualannya. Laporan berisi informasi yang merupakan keluaran sistem akuntansi.

\section{METODE PENGABDIAN}

Program pembinaaan dan pelatihan ini dilaksanakan dengan bekerjasama dengan Organisasi Gereja Masehi Advent Hari Ketujuh Daerah Koenferens Minahasa yang menaungi langsung Jemaat Gereja Masehi Advent Hari Ketujuh se-Wilayah Kecamatan Tondano Barat dan Tondano Selatan. Kegiatan pelatihan ini dilaksanakan pada tanggal 15 Mei 2016 yang bertempat di Aula Gereja Masehi Advent Hari Ketujuh Jemaat Tataaran, Kecamatan Tondano Selatan, Kabupaten Minahasa. Kegiatan dimulai pukul 09.00 - 17.00 Wita. Peserta pelatihan adalah Officer (Ketua, Sekretaris dan Bendahara) Jemaat GMAHK yang ada di wilayah Kecamatan Tondano Barat dan Selatan, yang hadir pada kesempatan tersebut berjumlah 15 orang.

Pada pelatihan ini, yang menjadi nara sumber adalah Bapak Joseph P. Kambey, SE, Ak, MBA. Nara sumber adalah Dosen Manajemen Keuangan Fakultas Ekonomi di Universitas Negeri Manado. Penyiapan materi pelatihan dilakukan oleh nara sumber berdasarkan pada aturanaturan terbaru di bidang akuntansi, termasuk standar akuntansi yang digunakan, yaitu SAK ETAP. Materi pelatihan juga termasuk bahan simulasi untuk membuat laporan keuangan yang benar sesuai kasus yang disiapkan oleh nara sumber termasuk formulir-formulir yang digunakan untuk pelatihan pembuatan laporan keuangan bagi organisasi keagamaan.

Pelasanaan kegiatan pengabdian ini diawali dengan koordinasi dengan pihak Pimpinan Wilayah Tandano Barat dan Selatan Gereja Masehi Hari Ketujuh, yang disambut dengan baik dan didukung oleh para staffnya. Selanjutnya kami menentukan jadwal dan tempat pelaksanaan kegitan pelatihan. Langkah berikutnya yang dilakukan adalah menyebarkan surat undangan kepada masing-masing officers organisasi keagamaan. Setelah diberikan jangka waktu tertentu, para peserta pelatihan memberikan konfirmasi kesediaan mengikuti kegiatan pelatihan ini disertai nama peserta masing-masing.

Pada hari pelaksanaan, kegiatan pengabdian ini dibagi menjadi dua sesi, yaitu: sesi pertama adalah penyampaian materi dan diskusi, kemudian sesi kedua adalah pembinaan dan pelatihan perencanaan keuangan berdasarkan bahan simulasi yang telah disiapkan.

Adapun materi yang diberikan antara lain tentang konsep pencatatan, pelaporan, pengauditan laporan keuangan berdasarkan pada standar SAK ETAP pada organisasi sosial kemasyarakatan serta perencanaan keuangan gereja. Selanjutnya materi tentang implementasi penerapan standar tersebut disertai contoh ilustrasi laporan keuangan. Pada sesi diskusi, para 
peserta sangat antusias dengan meteri yang disajikan beberapa pertanyaan dikemukakan oleh peserta dan dibahas dengan baik oleh nara sumber.

Pembinaan dan Pelatihan model pencatatan, pelaporan, pengauditan, dan perencanaan keuangan gereja, berjalan dengan baik. Para peserta dapat membuat laporan keuangan tersebut serta melakukan perencanaan keuangan dengan baik. Pada akhir kegiatan, hasil pelatihan yang dibuat oleh para peserta dibahas oleh nara sumber, dievaluasi kesalahannya, dan dibahas tentang kekeliruan yang terjadi pada saat pembuatan laporan keuangan tersebut.

\section{HASIL DAN PEMBAHASAN}

Pada pelaksanaan pengabdian tentang pelatihan ini dirasakan sangat bermanfaat bagi peserta pelatihan. Koordinasi dan kerjasama yang dilakukan antara LPM Unima dalam hal ini pelaksana kegiatan, sudah sangat baik. Pihak Organisasi Gereja Masehi Advent Hari Ketujuh sangat menyambut baik kegiatan yang dapat meningkatkan kemampuan para anggotanya melalui kerja sama dengan pihak Unima, terutama yang berkaitan dengan pendidikan dan pelatihan di bidang keuangan. Namun terdapat beberapa hal yang dapat menjadi masukan bagi pelaksana kegiatan ini, yaitu jumlah peserta yang diundang kurang dapat memenuhi harapan dari pelaksana, kami mengharapkan kegiatan seperti ini hendaknya dapat dilakukan dengan peserta 66 yang lebih banyak dari saat ini, karena kegiatan ini sangat penting untuk meningkatkan pemahaman mereka tentang penyusunan laporan keuangan organisasi sosial kemasyarakatan. Jika dilihat dari undangan yang disebarkan, kehadiran peserta saat pelatihan lebih dari cukup, yaitu telah mencapai 95\%, hal ini menunjukkan bahwa sasaran kegiatan ini sangat antusias mengikuti pelaksanaan kegiatan yang dilakukan ini.

Banyak pertanyaan dan diskusi yang dilakukan tidak dapat dibahas secara mendalam karena keterbatasan waktu pelaksanaan kegiatan. Selain itu pembuatan laporan keuangan sesuai standar SAK ETAP untuk masing-masing jenis organisasi yang mempunyai karakteristik yang berbeda, belum dapat didiskusikan secara maksimal. Hal ini selanjutnya memerlukan kegiatan pendampingan pembuatan laoran keuangan sesuai standar SAK ETAP organisasi yang masih kesulitan membuat laporan keuangan tersebut.

\section{KESIMPULAN DAN SARAN}

\section{Kesimpulan}

Berdasarkan hasil dan pembahasan kegiatan pengabdian kepada masyarakat yang telah diuraikan sebelumnya, dapat ditarik kesimpulan sebagai berikut:

1. Pemahaman peserta tentang pencatatan, pelaporan, pengauditan, laporan keuangan organisasi gereja semakin baik setelah mengikuti pelatihan penyusunan laporan 
keuangan, terutama bagi anggota yang terlibat langsung dalam proses penyusunan laporan keuangan.

2. Kemampuan peserta pelatihan melakukan perencanaan keuangan pada simulasi dengan bahan yang disiapkan telah cukup baik.

\section{Saran}

Berdasarkan uraian yang telah dikemukakan di atas, pada kesempatan ini dapat disarankan beberapa hal, yaitu:

1. Pelatihan tentang bidang ilmu akuntansi dan keuangan terutama proses dan pemahaman tentang pencatatan, pelaporan, pengauditan laporan keuangan sangat diperlukan oleh semua organisasi, sehingga diharapkan kegiatan seperti ini dapat berlanjut di kemudian hari.

2. Bagi para pengurus organisasi sosial di bidang accounting perlu melihat atau memperbaharui pengetahuan yang dimiliki, sesuai dengan perkembangan atau perubahan yang terjadi.

\section{KEPUSTAKAAN}

Bastian, I., 2009. Akuntansi Pendidikan. Erlangga. Jakarta.

Ikatan Akuntan Indonesia, 2012. Standar Akuntansi Keuangan. IAI. Jakarta.

Jusup, A. H., 2005. Dasar-dasar Akuntansi. STIE-YKPN. Yogyakarta.

Kristina, F. M., 2010. Studi atas akuntansi pada organisasi gereja yang dilihat dari sudut pandang pelaporan keuangan. Skripsi. STIE Perbanas, Surabaya.

Perkasa, I. R., 2009. Implementasi akuntansi pada organisasi keagamaan (Studi Kasus Pada Gereja Kristen Indonesia Pondok Tjandra Indah Sidoarjo). Skripsi. UPN Veteran. Surabaya.

Setiawan, T., 2009. Mahir Akuntansi. Bhuana Ilmu Populer. Jakarta.

Soemarso, S. R., 2005. Akuntansi: Suatu Pengantar. Ed.5. Salemba4. Jakarta. 
Jurnal ABDIMAS, Vol. 10, No. 01, Juni 2017 ISSN: 1979-0953 